(c) American Dairy Science Association, 2005.

\title{
Effects of Source of Gossypol and Supplemental Iron on Plasma Gossypol in Holstein Steers
}

\author{
J. E. P. Santos, ${ }^{1}$ H. Mena, ${ }^{2}$ J. T. Huber, ${ }^{2}$ and M. Tarazon ${ }^{2, *}$ \\ ${ }^{1}$ Veterinary Medicine Teaching and Research Center, University of California-Davis, Tulare 93274 \\ ${ }^{2}$ Department of Animal Science, University of Arizona-Tucson 85721-0038
}

\begin{abstract}
Four experiments were conducted to evaluate factors influencing concentrations of plasma total gossypol (TG) in 30 Holstein steers fed cottonseed products. At the end of each 28-d experiment, steers were weighed and blood samples were collected and analyzed for plasma TG concentrations. During the entire study, steers did not show any overt signs of gossypol toxicity. In the $28 \mathrm{~d}$ before experiment 1,30 steers with a body weight (BW) of $273 \mathrm{~kg}$ were fed a standardization diet with $15.0 \%$ Upland whole cottonseed (WCS) that resulted in a mean intake of $9.08 \mathrm{~g} / \mathrm{d}$ of TG per steer/d and a plasma TG of $1.66 \mu \mathrm{g} / \mathrm{mL}$. In experiment 1,30 steers were fed 1 of 5 diets with $15.0 \%$ Upland WCS, but different levels of supplemental $\mathrm{Fe}[0,150,300$, 450 , and $600 \mathrm{mg} / \mathrm{kg}$ of diet dry matter (DM)]. Average daily gain was not affected by level of $\mathrm{Fe}$ in the diet, but DM intake, plasma TG, and plasma TG response decreased linearly as $\mathrm{Fe}$ in diets increased. In experiment 2 , steers were fed diets with $15.0 \%$ Upland cottonseed as whole, cracked, roasted, cracked-roasted, or extruded. Analysis of the seed revealed that roasting or extrusion markedly reduced free gossypol (FG) content. Minor effects on animal performance were observed, but plasma TG decreased with roasting or extrusion of seeds, with the greatest reduction when the seed was cracked and then roasted. In experiment 3 , steers were fed 2 levels of WCS (7.0 or 14.0\% of DM) with 3 levels of cottonseed meal $(2.8,5.5$, or $8.5 \%$ of DM) in the diet. Animal performance was not altered by diet, but plasma gossypol concentrations and responses were greater in steers fed diets with more WCS, because of the greater FG intake. In experiment 4, 24 steers were fed diets with $15.0 \%$ cottonseed (Upland or Pima) either as whole or cracked. Pima cottonseed increased TG and FG intakes, which resulted in greater plasma TG concentra-
\end{abstract}

Received April 3, 2005.

Accepted June 23, 2005.

Corresponding author: J. E. P. Santos; e-mail: Jsantos@vmtrc. ucdavis.edu.

*Present address: Universidad de Sonora, Santa Ana, Sonora, 84600, Mexico. tion and response. Animal response to processing of cottonseed tended to differ according to type of cottonseed. However, feeding Pima and cracking of cottonseed increased gossypol availability and plasma TG concentrations.

(Key words: gossypol, whole cottonseed, cottonseed meal, iron sulfate)

Abbreviation key: $\mathbf{C S M}=$ cottonseed meal, $\mathbf{F G}=$ free gossypol, $\mathbf{P G}=$ plasma gossypol, $\mathbf{T G}=$ total gossypol, WCS $=$ whole cottonseed.

\section{INTRODUCTION}

Cotton is a major crop throughout the Southern United States and by-products of the cotton industry such as linted whole cottonseed (WCS) and cottonseed meal (CSM) are extensively used as dietary ingredients for dairy and beef cattle (Arieli, 1998). Upland cotton (Gossypium hirsutum) is the predominant type of cotton grown in many areas of the world, but Pima cotton (Gossypium barbedense) production is increasing in the Southwestern United States and other parts of the world (Lewkowitz, 2004). Upland cottonseed is generally fed unprocessed, but Pima cottonseed is naturally devoid of linters and is generally processed by cracking or grinding to increase digestion and nutrient use (Sullivan et al., 1993a,b), thus preventing the appearance of whole seeds in the feces.

Gossypol is a naturally occurring toxin produced by the pigment glands found throughout the cotton. However, gossypol concentration is greater in the kernels of cottonseed than other parts of the plant. Because of gossypol, the amount of cotton products fed to cattle has to be limited to avoid risk of toxicity (Coppock et al., 1987; Calhoun et al., 1995; Arieli, 1998). Gossypol exists in both the free and the bound forms. Most of the gossypol found in WCS is in the free form, whereas most of the gossypol in products of cottonseed treated with temperature and pressure, such as CSM, is in the bound form (Mena et al., 2001, 2004), which results in lower plasma gossypol (PG) concentrations (Mena et al., 2001, 2004). Gossypol also exists as a mixture of $(+)$ and (-) enantiomers, with the (-) isomer having the higher biological activity (Joseph et al., 1986). 
In a number of studies designed to evaluate the effects of feeding cottonseed products on animal performance, it was demonstrated that cattle with a welldeveloped rumen tolerated diets with high concentrations of total gossypol (TG) and free gossypol (FG) for extended periods (Coppock et al., 1987; Risco et al., 2002; Santos et al., 2002, 2003; Mena et al., 2004). Although ruminants with a functioning rumen detoxify gossypol to some extent (Calhoun et al., 1995), the mechanism of gossypol detoxification is not clearly understood (Coppock et al., 1987). Gossypol is thought to bind to proteins containing free amino sites, which impairs absorption of gossypol in the digestive tract (Reiser and Fu, 1962; Calhoun et al., 1995). Furthermore, it has been suggested that iron as iron sulfate binds to gossypol and reduces availability in the digestive tract for absorption (Barraza et al., 1991).

Plasma gossypol concentrations might reflect the availability of gossypol for absorption (Calhoun et al., 1995) and can be used to establish limits on amounts of cottonseed products that can be fed safely. Furthermore, type of cottonseed, concentrations of FG in cottonseed, particle size and density of cottonseed, processing method, and concentration of $\mathrm{Fe}$ in the diet are among the several factors that affect PG concentrations when cotton products are fed to ruminants.

The objectives of this study were to determine the effects of type and method of processing of cottonseed, supplementation with $\mathrm{Fe}$ from monohydrated iron sulfate $\left(\mathrm{FeSO}_{4} \cdot \mathrm{H}_{2} \mathrm{O}\right)$, and source of gossypol on PG concentrations in Holstein steers. Responses to treatments were evaluated in 4 experiments by measuring PG concentrations, $\mathrm{PG}$ response to gossypol intake, and animal performance. Although it was not the main objective of the study to determine animal performance, data on DM intake, BW gain, and efficiency of feed use were also evaluated.

\section{MATERIALS AND METHODS}

\section{Animals and Feeding}

Thirty Holstein steers with an initial average BW of $273 \mathrm{~kg}$ were selected for this study and subjected to 4 experiments of $28 \mathrm{~d}$ each. The University of Arizona Institutional Animal Care and Use Committee approved all procedures involving animals. Steers were housed in individual pens with shades and with free access to water and feed. Diets were offered for ad libitum intake twice daily and feed intake and refusals were recorded weekly. Diets were mixed twice for each of the experiments and samples of TMR, cottonseeds, and CSM were collected every time diets were mixed, dried at $55^{\circ} \mathrm{C}$ for $48 \mathrm{~h}$, and ground in a Wiley mill (Arthur H. Thomas Co., Philadelphia, PA) to pass through a 2-mm screen, then in a cyclone mill (Udy Co., Fort Collins, CO) to pass through a 1-mm screen. Samples were then stored at $-20^{\circ} \mathrm{C}$ for later analyses of DM, OM, N, ether extract (AOAC, 1990), ADF and NDF (Van Soest et al., 1991), and Fe by an inductively coupled plasma emission spectrometer (Thermo Jarrell Ash, Franklin, MA). Therefore, diets and cotton products were analyzed twice for each of the 4 experiments. Diets were kept as isonitrogenous as possible and formulated to meet nutritional requirements of Holstein steers gaining 1.5 to $1.7 \mathrm{~kg} / \mathrm{d}$ (NRC, 2001). Concentrations of gossypol in diets of all experiments were calculated based on the gossypol content of cotton products and their inclusion rate in the respective diets.

During the initial standardization period of $28 \mathrm{~d}$ before experiment 1 , all steers were fed a common standardization diet containing (DM basis) $15.0 \%$ Upland WCS, $37.0 \%$ alfalfa hay, $47.0 \%$ steam-flaked corn, and $1.0 \%$ of a mixture of minerals and vitamins. The nutritional composition of the standardization diet was: 91.8\% DM, 2.78 Mcal of metabolizable energy when adjusted for $10 \mathrm{~kg}$ of DM intake (NRC, 2001), 14.7\% $\mathrm{CP}, 6.1 \%$ ether extract, $30.3 \% \mathrm{NDF}, 141 \mathrm{mg}$ of $\mathrm{Fe} / \mathrm{kg}$ of diet, and $960 \mathrm{mg}$ of TG and FG/kg of diet. The nutrient composition of the Upland WCS was (DM basis) $19.3 \%$ CP, $18.6 \%$ crude fat, $51.3 \% \mathrm{NDF}, 40.7 \% \mathrm{ADF}$, and $1.61 \%$ $\mathrm{ADF}$ insoluble CP. Concentrations of PG and animal performance during the standardization period were used for covariate adjustment during analysis of data in experiment 1 .

Experimental periods lasted $28 \mathrm{~d}$ because we have demonstrated that this is the time required for $\mathrm{PG}$ to plateau after inclusion of gossypol in the diet (Mena et al., 2001, 2004). Furthermore, when the source of gossypol was removed from the diet, gossypol concentrations in plasma returned to undetected levels after $28 \mathrm{~d}$ (Mena et al., 2004). In all experiments, PG concentrations were used as an indicator of gossypol availability in cottonseed products.

In experiment 1 , the effects of monohydrated iron sulfate supplementation on the availability of gossypol from Upland linted WCS were studied by feeding the standardization diet $(960 \mathrm{mg} / \mathrm{kg}$ of TG and FG) and varying levels of $\mathrm{Fe}$ to 30 steers (6/treatment). Iron supplementation was designed to result in $0,150,300$, 450 , and $600 \mathrm{mg}$ of $\mathrm{Fe} / \mathrm{kg}$ of diet from iron sulfate, but actual concentrations of $\mathrm{Fe}$ in the diets after chemical analysis were $124,240,235,338$, and $457 \mathrm{mg} / \mathrm{kg}$, respectively (Table 1 ). The difference between the planned levels and those in the actual TMR may have been caused by difficulties in obtaining representative samples of the TMR for mineral analysis.

In experiment 2 , the effects of processing WCS on blood gossypol were evaluated in 30 steers (6/treat- 
Table 1. Ingredient and nutrient composition of diets varying in supplemental Fe (experiment 1).

\begin{tabular}{|c|c|c|c|c|c|}
\hline \multirow[b]{2}{*}{ Ingredient } & \multicolumn{5}{|c|}{ Dietary supplemental Fe, ${ }^{1} \mathrm{mg} / \mathrm{kg}$} \\
\hline & 0 & 150 & 300 & 450 & 600 \\
\hline & \multicolumn{5}{|c|}{$\longrightarrow(\%$ of $\mathrm{DM})$} \\
\hline Alfalfa hay & 37.0 & 37.0 & 37.0 & 37.0 & 37.0 \\
\hline Steam-flaked corn, $360 \mathrm{~g} / \mathrm{L}$ & 47.0 & 47.0 & 47.0 & 47.0 & 47.0 \\
\hline Whole linted cottonseed & 15.0 & 15.0 & 15.0 & 15.0 & 15.0 \\
\hline Mineral and vitamins ${ }^{2}$ & 1.0 & 1.0 & 1.0 & 1.0 & 1.0 \\
\hline \multicolumn{6}{|l|}{ Nutrient composition } \\
\hline $\mathrm{DM}, \%$ & 89.9 & 90.5 & 91.5 & 89.2 & 90.9 \\
\hline $\mathrm{ME},{ }^{3} \mathrm{Mcal} / \mathrm{kg}$ & 2.78 & 2.78 & 2.78 & 2.78 & 2.78 \\
\hline $\mathrm{OM}, \%$ & 94.5 & 94.3 & 94.1 & 94.0 & 94.2 \\
\hline $\mathrm{CP}, \%$ & 16.0 & 15.4 & 14.6 & 15.2 & 15.8 \\
\hline Ether extract, \% & 6.1 & 6.0 & 6.1 & 6.1 & 6.0 \\
\hline $\mathrm{NDF}, \%$ & 34.9 & 36.8 & 41.3 & 39.0 & 36.6 \\
\hline $\mathrm{ADF}, \%$ & 24.9 & 24.7 & 27.4 & 28.3 & 26.3 \\
\hline $\mathrm{Fe}, \mathrm{mg} / \mathrm{kg}$ & 124.0 & 240.0 & 235.0 & 338.0 & 457.0 \\
\hline Total gossypol, ${ }^{4} \mathrm{mg} / \mathrm{kg}$ & 960.0 & 960.0 & 960.0 & 960.0 & 960.0 \\
\hline Free gossypol, ${ }^{4} \mathrm{mg} / \mathrm{kg}$ & 960.0 & 960.0 & 960.0 & 960.0 & 960.0 \\
\hline \multicolumn{6}{|c|}{$\begin{array}{l}\left.{ }^{2} \mathrm{Ca}, 4.68 \% ; \mathrm{P}, 4.14 \% ; \mathrm{Mg}, 7.60 \% \text {; } \mathrm{Na}, 9.70 \% \text {; Cl, } 3.90 \% ; \mathrm{S}, 2.46 \% \text {; and (per } \mathrm{kg}\right) 480 \mathrm{mg} \text { of } \mathrm{Zn}, 960 \mathrm{mg} \text { of } \\
\text { Mn, } 18 \mathrm{mg} \text { of I, } 360 \mathrm{mg} \text { of } \mathrm{Cu}, 6 \mathrm{mg} \text { of } \mathrm{Co}, 6 \mathrm{mg} \text { of Se, } 40,200 \mathrm{IU} \text { of vitamin A, } 420 \mathrm{IU} \text { of vitamin E, and } \\
4020 \mathrm{IU} \text { of vitamin D. }\end{array}$} \\
\hline \multicolumn{6}{|c|}{$\begin{array}{l}{ }^{3} \text { Metabolizable energy (ME) content of the diets according to NRC (2001) adjusted for a DM intake of } 10 \\
\mathrm{~kg} / \mathrm{d} \text {. }\end{array}$} \\
\hline
\end{tabular}

ment) by feeding $15 \%$ of the diet as linted Upland WCS, or the same cottonseed processed as cracked cottonseed, roasted WCS, roasted-cracked cottonseed, or extruded cottonseed (Table 2). The WCS was coarsely cracked by passing the seed through rollers. The particle size of the seed was calculated after sieving approximately 300 $\mathrm{g}$ for $3 \mathrm{~min}$ in a Ro-Tap Testing Sieve Shaker (model B; C-E Tyler Combustion Engineering, Inc., Bessemer City, NC) through a series of sieves with mesh sizes of $5.60,4.75,3.75,2.36,1.70,1.00$, and $0.60 \mathrm{~mm}$, and the bottom pan (Table 2). Based on the proportion of each seed retained in the different sieves, processed cottonseeds were all smaller than the original WCS. The WCS was roasted at $150^{\circ} \mathrm{C}$ for 25 to 30 min with hot air in a commercial roaster (Jet-Pro, Inc., Springfield, $\mathrm{OH}$ ) and cooled by spreading on the ground. For roastedcracked cottonseed, the WCS was initially coarsely cracked by running it through rollers and then roasted as described previously. The WCS was extruded using a dry system, the Insta-Pro extrusion process (InstaPro Int., Division of Triple "F", Inc., Des Moines, IA), which removes 70 to $80 \%$ of fat in the seed. Because of the lower fat $(4.9 \%$ of $\mathrm{DM})$ and higher $\mathrm{CP}(24.2 \%$ of DM) content of the extruded cottonseed compared with the unprocessed WCS (18.1\% crude fat and $19.7 \% \mathrm{CP}$ ), this treatment diet was supplemented with $2.5 \% \mathrm{Ca}$ salts of palm fatty acids (Megalac, Church \& Dwight Co., Inc., Princeton, NJ) to achieve a fat and energy content comparable with other diets. Processing of cottonseed by roasting or extrusion increased the insoluble $\mathrm{CP}$ in ADF from (mean \pm SD) $7.8 \pm 0.8 \%$ of CP in WCS to $13.2 \pm 0.9,16.2 \pm 1.1$, and $11.7 \pm 0.5 \%$ of $\mathrm{CP}$ in roasted, roasted-cracked, and extruded cottonseeds, respectively. This increase in the content of ADF insoluble protein was expected to reduce the degradability of $\mathrm{CP}$, especially in roasted-cracked cottonseed.

In experiment 3 , the effects of increasing dietary gossypol concentrations from feeding varying amounts of WCS and CSM were evaluated when the diets were arranged in a $2 \times 3$ factorial, with 2 concentrations of Upland WCS (7.0 or $14.0 \%$ of the DM) and 3 of CSM $(2.8,5.7$, or $8.5 \%$ of the DM). Thirty Holstein steers (5/ treatment) were fed the following diets: WCS $7.0 \%$ and CSM $2.8 \%$ resulting in $500 \mathrm{mg} / \mathrm{kg}$ TG from WCS and $400 \mathrm{mg} / \mathrm{kg}$ TG from CSM; WCS 7.0\% and CSM 5.7\% resulting in $500 \mathrm{mg} / \mathrm{kg}$ TG from WCS and $800 \mathrm{mg} / \mathrm{kg}$ TG from CSM; WCS $7.0 \%$ and CSM 8.5\% resulting in $500 \mathrm{mg} / \mathrm{kg}$ TG from WCS and $1200 \mathrm{mg} / \mathrm{kg}$ TG from CSM; WCS $14.0 \%$ and CSM $2.8 \%$ resulting in $1000 \mathrm{mg} /$ $\mathrm{kg}$ TG from WCS and $400 \mathrm{mg} / \mathrm{kg}$ TG from CSM; WCS $14.0 \%$ and CSM $5.7 \%$ resulting in $1000 \mathrm{mg} / \mathrm{kg}$ TG from WCS and $800 \mathrm{mg} / \mathrm{kg}$ TG from CSM; and, WCS $14.0 \%$ and CSM 8.5\% resulting in $1000 \mathrm{mg} / \mathrm{kg}$ TG from WCS and $1200 \mathrm{mg} / \mathrm{kg}$ TG from CSM (Table 3). Upland WCS contained (DM basis) $20.1 \% \mathrm{CP}, 18.9 \%$ crude fat, $49.8 \%$ $\mathrm{NDF}, 39.8 \% \mathrm{ADF}$, and $1.63 \% \mathrm{ADF}$ insoluble CP. Cotton- 
Table 2. Ingredient and nutrient composition of diets varying in type of cottonseed (experiment 2).

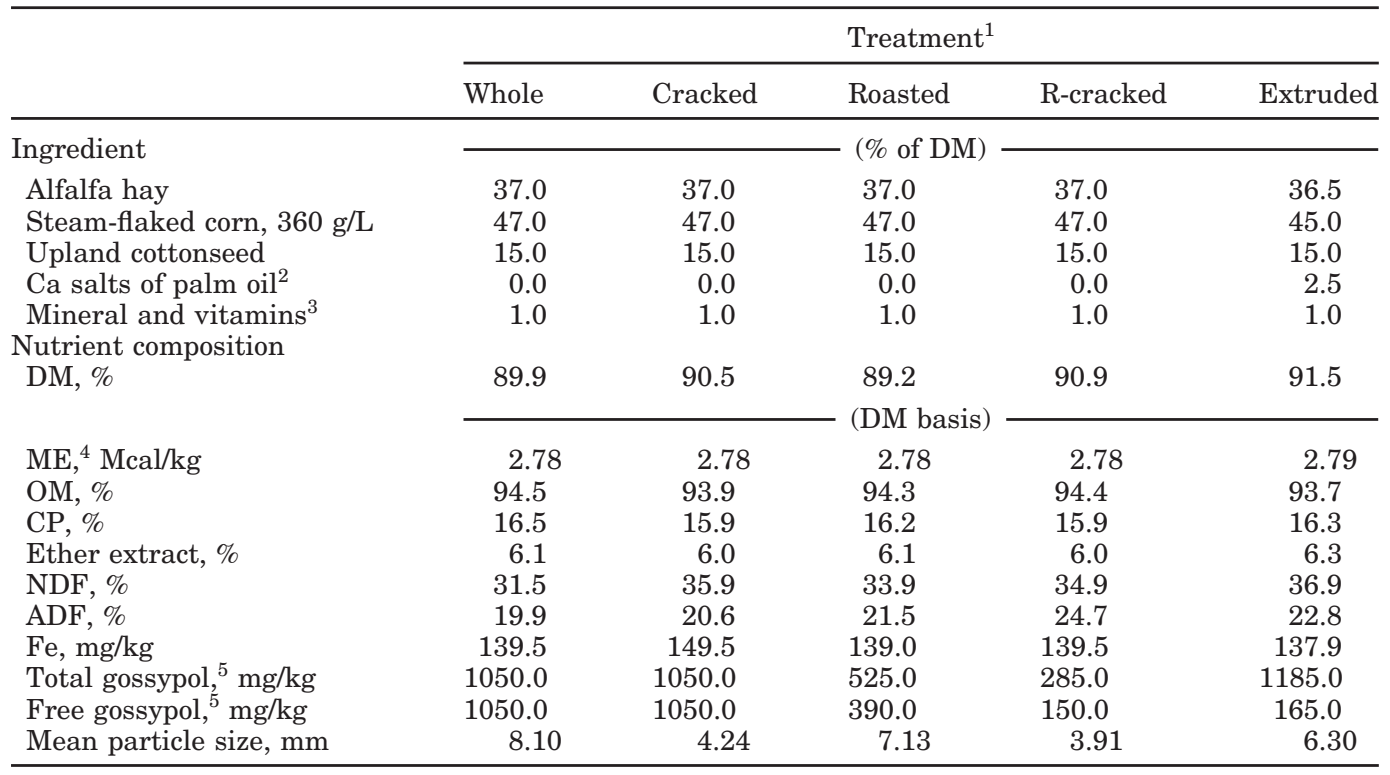

${ }^{1}$ Whole = Whole Upland cottonseed; Cracked = cracked Upland cottonseed; Roasted = roasted Upland cottonseed; R-cracked = roasted-cracked Upland cottonseed; and Extruded = extruded Upland cottonseed.

${ }^{2}$ Megalac (Church \& Dwight Co., Inc., Princeton, NJ).

${ }^{3} \mathrm{Ca}, 4.68 \%$; P, 4.14\%; $\mathrm{Mg}, 7.60 \%$; Na, 9.70\%; Cl, 3.90\%; S, 2.46\%; and (per kg) $480 \mathrm{mg}$ of Zn, $960 \mathrm{mg}$ of $\mathrm{Mn}, 18 \mathrm{mg}$ of I, $360 \mathrm{mg}$ of $\mathrm{Cu}, 6 \mathrm{mg}$ of Co, $6 \mathrm{mg}$ of Se, 40,200 IU of vitamin A, $420 \mathrm{IU}$ of vitamin E, and 4020 IU of vitamin D.

${ }^{4}$ Metabolizable energy (ME) content of the diets according to NRC (2001) adjusted for a DM intake of 10 $\mathrm{kg} / \mathrm{d}$.

${ }^{5}$ Calculated based on gossypol content of cottonseeds.

seed meal was produced by solvent extraction of the oil and it contained (DM basis) $41.3 \% \mathrm{CP}, 1.8 \%$ crude fat, $32.4 \% \mathrm{NDF}, 20.9 \% \mathrm{ADF}$, and $1.92 \% \mathrm{ADF}$ insoluble $\mathrm{CP}$.

In experiment 4 , the effects of type of cottonseed and processing method were evaluated using 24 steers (6/ treatment) in a $2 \times 2$ factorial arrangement of treatments by feeding $15.0 \%$ of diet DM as cottonseed from Upland cotton or Pima cotton, and both cottonseeds were either fed as whole or cracked (Table 4). The Upland WCS contained (DM basis) $19.5 \% \mathrm{CP}, 18.9 \%$ crude fat, $49.4 \% \mathrm{NDF}, 40.2 \% \mathrm{ADF}$, and $1.54 \% \mathrm{ADF}$ insoluble CP. The Pima cottonseed contained (DM basis) $22.1 \%$ $\mathrm{CP}, 22.4 \%$ crude fat, $45.2 \% \mathrm{NDF}, 34.1 \% \mathrm{ADF}$, and $1.68 \%$ $\mathrm{ADF}$ insoluble CP. Cottonseeds were coarsely cracked as described previously and mean particle sizes for cracked Upland and Pima cottonseeds were 3.45 and $3.88 \mathrm{~mm}$, respectively.

Steers were weighed the day before the start and on the last day of each of the 4 experiments; average BW between the start and the end of each of the experiments was used to determine PG responses. Plasma TG and FG responses were calculated as the ratio between plasma TG concentration and the daily intake of TG and FG, respectively, per kilogram of BW per day. These variables were evaluated as indicators of gossypol avail- ability for absorption based on changes in plasma TG in response to consumption of TG and FG relative to BW of the animals.

\section{Gossypol Analyses}

The official methods of the American Oil Chemist's Society were used to determine free (AOCS, 1985a) and total (AOCS, 1985b) gossypol in cottonseed products. For analysis of cottonseeds, the seeds were decorticated before analyses and the actual analyses were run on decorticated seed (i.e., cottonseed kernels). High performance liquid chromatography was used to quantify the isomers of gossypol in cottonseed products as described previously (Mena et al., 2001) following the method of Hron et al. (1999).

Blood samples $(10 \mathrm{~mL})$ were collected at the end of standardization period, as well as the end of each experiment, simultaneously with measurements of BW of steers. Samples were collected by puncture of the median coccygeal vein or artery using Vacutainer tubes (Becton Dickinson, Franklin Lakes, NJ) containing sodium heparin. Samples were immediately placed on ice and transported to the laboratory within $3 \mathrm{~h}$ of collection. Blood tubes were centrifuged at $2000 \times g$ for 15 
Table 3. Ingredient and nutrient composition of diets varying in source of gossypol (experiment 3).

\begin{tabular}{|c|c|c|c|c|c|c|}
\hline \multirow{3}{*}{$\begin{array}{l}\text { Whole cottonseed, \%: } \\
\text { Cottonseed meal, \%: }\end{array}$} & \multicolumn{6}{|c|}{ Treatment $^{1}$} \\
\hline & 7.0 & 7.0 & 7.0 & 14.0 & 14.0 & 14.0 \\
\hline & 2.8 & 5.7 & 8.5 & 2.8 & 5.7 & 8.5 \\
\hline \multicolumn{7}{|l|}{ Ingredients } \\
\hline Alfalfa hay & 46.0 & 45.2 & 45.2 & 38.0 & 38.0 & 38.0 \\
\hline Steam-flaked corn, $360 \mathrm{~g} / \mathrm{L}$ & 43.2 & 41.1 & 38.3 & 44.2 & 41.3 & 38.5 \\
\hline Whole linted cottonseed & 7.0 & 7.0 & 7.0 & 14.0 & 14.0 & 14.0 \\
\hline Cottonseed meal & 2.8 & 5.7 & 8.5 & 2.8 & 5.7 & 8.5 \\
\hline Mineral and vitamins ${ }^{2}$ & 1.0 & 1.0 & 1.0 & 1.0 & 1.0 & 1.0 \\
\hline \multicolumn{7}{|l|}{ Nutrient composition } \\
\hline $\mathrm{DM}, \%$ & 87.9 & 90.8 & 89.0 & 89.2 & 90.3 & 90.0 \\
\hline $\mathrm{ME}^{3} \mathrm{Mcal} / \mathrm{kg}$ & 2.71 & 2.70 & 2.69 & 2.77 & 2.75 & 2.74 \\
\hline $\mathrm{OM}, \%$ & 93.7 & 93.9 & 93.9 & 94.1 & 93.7 & 93.7 \\
\hline $\mathrm{CP}, \%$ & 17.0 & 16.0 & 17.9 & 17.5 & 16.3 & 17.6 \\
\hline Ether extract, \% & 4.7 & 4.6 & 4.5 & 5.9 & 5.8 & 5.7 \\
\hline $\mathrm{NDF}, \%$ & 35.3 & 37.1 & 32.1 & 36.9 & 40.1 & 36.7 \\
\hline $\mathrm{ADF}, \%$ & 23.9 & 30.0 & 19.6 & 27.2 & 29.9 & 28.8 \\
\hline $\mathrm{Fe}, \mathrm{mg} / \mathrm{kg}$ & 149.9 & 154.0 & 159.5 & 145.4 & 150.8 & 156.3 \\
\hline Total gossypol, ${ }^{4} \mathrm{mg} / \mathrm{kg}$ & 900.0 & 1300.0 & 1700.0 & 1400.0 & 1800.0 & 2200.0 \\
\hline Free gossypol, ${ }^{4} \mathrm{mg} / \mathrm{kg}$ & 531.0 & 562.0 & 594.0 & 1031.0 & 1062.0 & 1094.0 \\
\hline
\end{tabular}

${ }^{1}$ Whole cottonseed (WCS) $7.0 \%$ and cottonseed meal (CSM) $2.8 \%=500 \mathrm{mg} / \mathrm{kg}$ total gossypol (TG) from WCS and $400 \mathrm{mg} / \mathrm{kg}$ TG from CSM; WCS 7.0\% and CSM $5.7 \%=500 \mathrm{mg} / \mathrm{kg}$ TG from WCS and $800 \mathrm{mg} / \mathrm{kg}$ TG from CSM; WCS $7.0 \%$ and CSM $8.5 \%=500 \mathrm{mg} / \mathrm{kg}$ TG from WCS and $1200 \mathrm{mg} / \mathrm{kg}$ TG from CSM; WCS $14.0 \%$ and CSM $2.8 \%=1000 \mathrm{mg} / \mathrm{kg}$ TG from WCS and $400 \mathrm{mg} / \mathrm{kg}$ TG from CSM; WCS $14.0 \%$ and CSM $5.7 \%=1000 \mathrm{mg} / \mathrm{kg}$ TG from WCS and $800 \mathrm{mg} / \mathrm{kg}$ TG from CSM; and WCS $14.0 \%$ and CSM $8.5 \%=1000$ $\mathrm{mg} / \mathrm{kg}$ TG from WCS and $1200 \mathrm{mg} / \mathrm{kg}$ TG from CSM.

${ }^{2} \mathrm{Ca}, 4.68 \%$; P, 4.14\%; Mg, 7.60\%; Na, 9.70\%; Cl, 3.90\%; S, 2.46\%; and (per kg) $480 \mathrm{mg}$ of Zn, $960 \mathrm{mg}$ of $\mathrm{Mn}, 18 \mathrm{mg}$ of I, $360 \mathrm{mg}$ of $\mathrm{Cu}, 6 \mathrm{mg}$ of Co, $6 \mathrm{mg}$ of Se, 40,200 IU of vitamin A, $420 \mathrm{IU}$ of vitamin E, and 4020 IU of vitamin D.

${ }^{3}$ Metabolizable energy (ME) content of the diets according to NRC (2001) adjusted for a DM intake of 10 $\mathrm{kg} / \mathrm{d}$.

${ }^{4}$ Calculated based on gossypol content of WCS and CSM.

min in a refrigerated centrifuge $\left(\sim 5^{\circ} \mathrm{C}\right)$ for plasma separation. Plasma was frozen at $-12^{\circ} \mathrm{C}$ and later analyzed for gossypol. Total gossypol in plasma was analyzed by HPLC (Kim and Calhoun, 1995).

\section{Experimental Design and Statistical Analyses}

The experiments were completely randomized with blocks (Kuehl, 1994). In each of the 4 experiments, steers were blocked according to BW the day before the start of each experiment and, within each block, randomly assigned to one of the different treatments. Therefore, steers were blocked and re-randomized between each experiment. Data from the initial standardization period were used for covariate adjustment for the analysis of experiment 1 . For experiments 2,3 , and 4 , data from the previous experiment were used for covariate adjustment during statistical analyses (e.g., for experiment 2 , data from experiment 1 was used as covariate). In experiments 3 and 4 , treatments were arranged in a $2 \times 3$ and a $2 \times 2$ factorial, respectively. All data were analyzed by ANOVA (Littell et al., 2002) using the GLM procedure of SAS (SAS Institute, 2001).
The statistical model included the effects of block, treatment, covariate, and the random experimental error. In experiment 1 , orthogonal polynomials (linear, quadratic, and cubic) were performed to evaluate response to iron sulfate supplementation on PG concentrations and performance variables. Furthermore, because supplemental Fe suppressed gossypol intake in experiment 1, PG concentration and PG response were also analyzed with gossypol intake as a covariate in the statistical model. In experiments 3 and 4, the interaction between level of WCS and CSM, and the interaction between type of cottonseed and method of processing, respectively, were included in the statistical model. Least square means are reported for all parameters evaluated. Treatment differences with $P<0.05$ were considered significant and $P \leq 0.10$ were considered a tendency. In experiment 2 , when a treatment effect was observed $(P \leq 0.10)$ for the ANOVA, individual comparisons were then performed using the PDIFF statement in SAS (SAS Institute, 2001).

Multiple regression analyses utilizing the best subset regression procedure of Minitab (Minitab Inc., 2000) were performed to determine the best predictors for $\mathrm{PG}$ 
Table 4. Ingredient and nutrient composition of diets varying in type of cottonseed (experiment 4).

\begin{tabular}{|c|c|c|c|c|}
\hline & \multicolumn{4}{|c|}{ Treatment } \\
\hline & \multicolumn{2}{|c|}{ Upland cottonseed } & \multicolumn{2}{|c|}{ Pima cottonseed } \\
\hline & Whole & Cracked & Whole & Cracked \\
\hline \multicolumn{5}{|c|}{$(\%$ of $\mathrm{DM})$} \\
\hline Alfalfa hay & 37.0 & 37.0 & 37.0 & 37.0 \\
\hline Steam-flaked corn, $360 \mathrm{~g} / \mathrm{L}$ & 47.0 & 47.0 & 47.0 & 47.0 \\
\hline Cottonseed & 15.0 & 15.0 & 15.0 & 15.0 \\
\hline Mineral and vitamins ${ }^{1}$ & 1.0 & 1.0 & 1.0 & 1.0 \\
\hline \multicolumn{5}{|l|}{ Nutrient composition } \\
\hline DM, \% & 90.3 & 90.3 & 90.0 & 89.9 \\
\hline $\mathrm{ME},{ }^{2} \mathrm{Mcal} / \mathrm{kg}$ & 2.78 & 2.78 & 2.78 & 2.78 \\
\hline $\mathrm{OM}, \%$ & 93.2 & 93.3 & 93.7 & 93.3 \\
\hline $\mathrm{CP}, \%$ & 16.4 & 16.0 & 15.7 & 15.7 \\
\hline Ether extract, \% & 5.9 & 6.0 & 6.1 & 6.2 \\
\hline $\mathrm{NDF}, \%$ & 36.3 & 34.3 & 31.1 & 31.1 \\
\hline $\mathrm{ADF}, \%$ & 22.9 & 24.7 & 18.9 & 18.7 \\
\hline $\mathrm{Fe}, \mathrm{mg} / \mathrm{kg}$ & 139.5 & 137.6 & 138.0 & 134.5 \\
\hline Total gossypol, ${ }^{3} \mathrm{mg} / \mathrm{kg}$ & 1000.0 & 1000.0 & 1200.0 & 1200.0 \\
\hline Free gossypol, ${ }^{3} \mathrm{mg} / \mathrm{kg}$ & 998.0 & 998.0 & 1200.0 & 1200.0 \\
\hline
\end{tabular}

${ }^{1} \mathrm{Ca}, 4.68 \% ; \mathrm{P}, 4.14 \% ; \mathrm{Mg}, 7.60 \% ; \mathrm{Na}, 9.70 \% ; \mathrm{Cl}, 3.90 \% ; \mathrm{S}, 2.46 \%$; and (per kg) $480 \mathrm{mg}$ of $\mathrm{Zn}, 960 \mathrm{mg}$ of $\mathrm{Mn}, 18 \mathrm{mg}$ of I, $360 \mathrm{mg}$ of $\mathrm{Cu}, 6 \mathrm{mg}$ of $\mathrm{Co}, 6 \mathrm{mg}$ of Se, 40,200 IU of vitamin A, $420 \mathrm{IU}$ of vitamin E, and 4020 IU of vitamin D.

${ }^{2}$ Metabolizable energy (ME) content of the diets according to NRC (2001) adjusted for a DM intake of 10 $\mathrm{kg} / \mathrm{d}$.

${ }^{3}$ Calculated based on gossypol content of cottonseeds.

concentrations using TG, FG, and $\mathrm{BG}$ intakes as the predictor variables for experiments 2 and 3 .

\section{RESULTS AND DISCUSSION}

During the standardization period, mean BW of the 30 steers was $297.1 \mathrm{~kg}$, and the TG content of the Upland linted WCS was $0.64 \%$ [58.8\% (+) isomer and $41.2 \%$ (-) isomer] and it was all FG. Therefore, dietary TG and FG, as well as intakes of TG and FG were identical. Feeding a diet containing 15.0\% linted WCS resulted in daily DM and TG intakes of 9.41 and $9.1 \mathrm{~g} /$ $\mathrm{d}$, respectively. The steers had an average daily consumption of $30.9 \mathrm{mg}$ of TG/kg of BW resulting in plasma TG concentrations that averaged $1.66 \mu \mathrm{g} / \mathrm{mL}$, with a range from 1.08 to $2.36 \mu \mathrm{g} / \mathrm{mL}$. No clinical signs of gossypol toxicity were observed in any of the steers during the standardization period.

\section{Experiment 1}

In experiment 1 , the same WCS of the standardization period was used. Mean BW of steers were similar across treatments (Table 5). Dry matter and TG intakes declined $(P<0.05)$ linearly with increasing concentrations of supplemental $\mathrm{Fe}$ from iron sulfate in the diet. Because animals had similar BW and diets contained the same TG and FG concentrations, but supplemental
Fe as iron sulfate depressed DM intake, gossypol intake relative to the $\mathrm{BW}$ of the animal was also suppressed $(P<0.05)$ with supplemental Fe. Supplemental Fe up to $500 \mathrm{mg} / \mathrm{kg}$ of diet DM suppressed DM intake of lactating dairy cows fed diets high in gossypol from Pima cottonseed (McCaughey et al., accepted). When lactating dairy cows were fed either soybean meal or WCS, supplemental Fe from iron sulfate at $500 \mathrm{mg} / \mathrm{kg}$ reduced DM intake in the soybean diet, but not in the WCS diet (Barraza et al., 1991).

Plasma gossypol concentrations decreased $(P<0.001)$ with increasing supplemental Fe. Plasma TG response, which was evaluated as the ratio between plasma TG and TG intake as $\mathrm{mg} / \mathrm{kg}$ of BW/d, also declined $(P<$ 0.001 ) linearly with increasing supplemental dietary Fe. These responses suggest that supplemental iron sulfate reduced PG likely by reducing gossypol availability in the digestive tract of steers (Barraza et al., 1991). Because supplemental Fe also reduced DM and TG intakes, it is possible that changes in PG concentrations were influenced by gossypol intake. However, when plasma TG concentrations and TG response were analyzed with gossypol intake as a covariate in the statistical model, similar linear decreases $(P<0.01)$ in PG were observed, reinforcing the idea that the decline in PG concentrations and plasma TG response were caused by the detoxifying effect of $\mathrm{Fe}$, and not by the decrease in intake. These results are in agreement with 
Table 5. Effect of addition of Fe from iron sulfate on plasma gossypol and performance of steers (experiment 1).

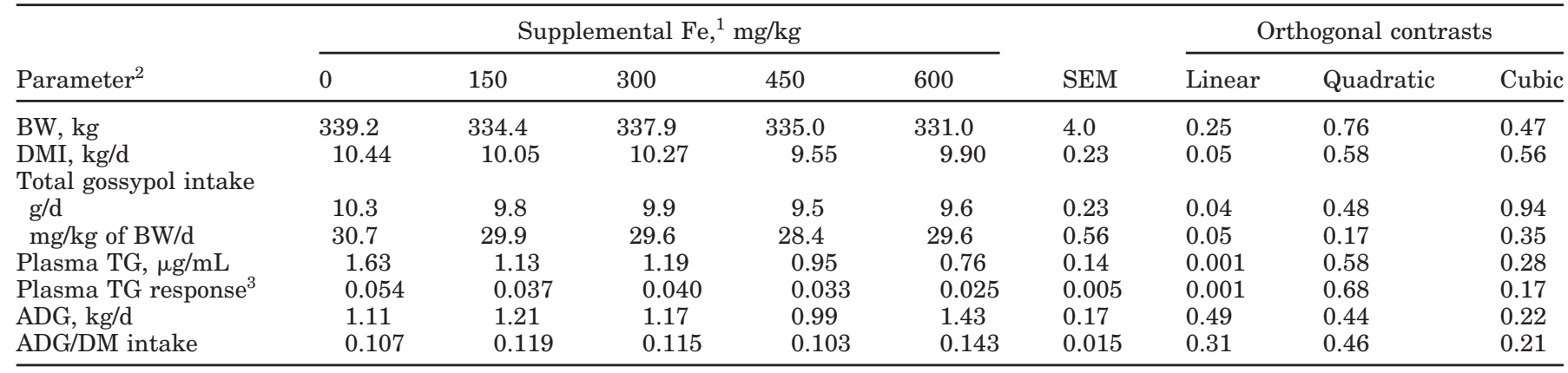

${ }^{1}$ Iron sulfate $\left(\mathrm{FeSO}_{4} \cdot \mathrm{H}_{2} \mathrm{O}, 30 \% \mathrm{Fe}\right)$ was added to the diets to alter the Fe content.

${ }^{2} \mathrm{TG}=$ Total gossypol; $\mathrm{ADG}=$ average daily BW gain.

${ }^{3}$ Plasma TG/TG intake $\mathrm{mg} / \mathrm{kg}$ of BW/d.

other studies in which supplemental dietary Fe reduced gossypol availability as evaluated by PG concentrations (McCaughey et al., accepted) or by the increased fecal gossypol excretion (Barraza et al., 1991). Although the study was designed to evaluate PG responses and not animal performance, average daily BW gain and feed efficiency were not affected by treatment. No signs of overt gossypol poisoning were observed in any steer.

\section{Experiment 2}

In experiment 2 , steers were fed diets containing $15.0 \%$ Upland cottonseed that was fed either as whole, coarsely cracked, roasted, coarsely cracked and roasted, or extruded to determine the effect of processing of cottonseed on PG concentrations.

The mean particle size of WCS was reduced after processing (Table 2). Extrusion reduced the fat content from $18.6 \%$ in the original WCS to $4.9 \%$ in the extruded cottonseed, but it increased the CP content from 19.3 to $24.2 \%$. Processing of cottonseed by roasting increased the insoluble CP in ADF from $7.8 \pm 0.8 \%$ of $\mathrm{CP}$ in WCS to $13.2 \pm 0.9$ and $16.2 \pm 1.1 \%$ of $\mathrm{CP}$ in roasted and roasted-cracked cottonseeds, respectively. Similarly, extrusion increased the insoluble $\mathrm{CP}$ in $\mathrm{ADF}$ to $11.7 \pm$ $0.5 \%$ of $\mathrm{CP}$.

Upland WCS contained $0.70 \%$ TG $[59.7 \%(+)$ and $40.3 \%$ (-) isomers] all of which was FG; roasted Upland WCS contained $0.35 \%$ TG $[63.3 \%(+)$ and $36.7 \%$ (-) isomers] with $0.26 \%$ FG; roasted-cracked Upland cottonseed contained $0.19 \%$ TG [63.9\% (+) and $36.1 \%$ (-) isomers] with $0.10 \% \mathrm{FG}$; and extruded Upland cottonseed contained $0.79 \%$ TG $[57.5 \%(+)$ and $42.5 \%(-)$ isomers] and $0.11 \%$ FG. Roasting of the Upland WCS reduced TG 50.0 and $73.0 \%$ and FG 63.0 and $86.0 \%$ in the wholeroasted and roasted-cracked samples, respectively. Extruding did not alter TG, but reduced FG $86.0 \%$. These results are in agreement with those of Barraza et al.
(1991), who reported a reduction in TG and FG after pelleting Upland WCS. Gossypol glands are sensitive to changes in temperature and moisture, and processing methods that apply heat such as roasting and the extrusion process normally reduce the FG content of cottonseed by either reducing the TG content, such as in roasting, or by increasing the bound gossypol content, such as in extruding process.

Body weight and DM intake of steers were similar among the different diets (Table 6). Small differences were observed for average daily BW gain and feed efficiency. Gain of BW was highest for steers fed extruded WCS and it was greater $(P<0.05)$ than that of steers fed roasted-cracked cottonseed, which resulted in improved $(P<0.10)$ feed efficiency for extruded compared with roasted-cracked cottonseed. It is not clear why roastedcracked cottonseed reduced BW gain, which tended to affect efficiency of feed use, but it is possible that roasting of cracked seed could have limited protein digestion in the rumen and small intestine, thereby affecting animal performance. When the seed was cracked and roasted, the content of ADF insoluble $\mathrm{CP}$ increased from $7.8 \%$ in the WCS to $16.2 \%$ of CP.

Total gossypol intake as grams/day or as milligrams/ kilogram of BW/day reflected the TG content of the seeds, and the slightly higher TG content in extruded cottonseed increased $(P<0.05)$ TG intake compared with steers consuming linted Upland cottonseed fed whole or cracked. However, roasting of cottonseed reduced $(P<0.05)$ TG intake, with lowest intake when the seed was cracked and then roasted. Similar to TG intake, FG intake also reflected the FG content in the seeds. Diets containing extruded or roasted-cracked cottonseeds reduced $(P<0.05) \mathrm{FG}$ intakes as grams/day or as milligrams/kilogram of BW/day compared with other diets. When cottonseed was only roasted, it reduced $(P<0.05)$ FG intake compared with linted Upland cottonseed fed either whole or cracked; and cracking 
Table 6. Effect of processing of Upland cottonseed on plasma gossypol and performance of steers (experiment 2).

\begin{tabular}{|c|c|c|c|c|c|c|}
\hline \multirow[b]{2}{*}{ Parameter $^{2}$} & \multicolumn{5}{|c|}{ Treatment $^{1}$} & \multirow[b]{2}{*}{ SEM } \\
\hline & Whole & Cracked & Roasted & R-cracked & Extruded & \\
\hline $\mathrm{BW}, \mathrm{kg}$ & 383.8 & 392.9 & 385.3 & 378.5 & 393.8 & 5.94 \\
\hline DMI, kg/d & 9.55 & 9.55 & 9.89 & 9.08 & 10.25 & 0.55 \\
\hline \multicolumn{7}{|l|}{ Total gossypol intake } \\
\hline $\mathrm{g} / \mathrm{d}$ & $10.12^{\mathrm{b}}$ & $9.97^{\mathrm{b}}$ & $5.28^{\mathrm{c}}$ & $2.58^{\mathrm{d}}$ & $12.20^{\mathrm{a}}$ & 0.42 \\
\hline $\mathrm{mg} / \mathrm{kg}$ of BW/d & $26.59^{b}$ & $25.53^{\mathrm{b}}$ & $13.90^{\mathrm{c}}$ & $6.96^{\mathrm{d}}$ & $30.95^{\mathrm{a}}$ & 0.92 \\
\hline \multicolumn{7}{|l|}{ Free gossypol intake } \\
\hline $\mathrm{g} / \mathrm{d}$ & $10.26^{\mathrm{a}}$ & $10.08^{\mathrm{a}}$ & $3.77^{\mathrm{b}}$ & $1.42^{\mathrm{c}}$ & $1.66^{\mathrm{c}}$ & 0.33 \\
\hline $\mathrm{mg} / \mathrm{kg}$ of $\mathrm{BW} / \mathrm{d}$ & $26.80^{\mathrm{a}}$ & $25.76^{\mathrm{a}}$ & $10.24^{\mathrm{b}}$ & $4.00^{\mathrm{c}}$ & $3.90^{\mathrm{c}}$ & 0.84 \\
\hline Plasma TG, $\mu \mathrm{g} / \mathrm{mL}$ & $1.19^{\mathrm{a}}$ & $1.44^{\mathrm{a}}$ & $0.81^{\mathrm{b}}$ & $0.18^{\mathrm{c}}$ & $0.74^{\mathrm{b}}$ & 0.11 \\
\hline Plasma TG response ${ }^{3}$ & $0.045^{\mathrm{b}}$ & $0.054^{\mathrm{ab}}$ & $0.057^{\mathrm{a}}$ & $0.030^{\mathrm{c}}$ & $0.024^{\mathrm{c}}$ & 0.004 \\
\hline Plasma FG response ${ }^{4}$ & $0.045^{\mathrm{c}}$ & $0.055^{\mathrm{c}}$ & $0.078^{\mathrm{b}}$ & $0.053^{\mathrm{c}}$ & $0.188^{\mathrm{a}}$ & 0.007 \\
\hline $\mathrm{ADG}, \mathrm{kg} / \mathrm{d}$ & $1.41^{\mathrm{ab}}$ & $1.67^{\mathrm{ab}}$ & $1.45^{\mathrm{ab}}$ & $1.29^{\mathrm{b}}$ & $1.89^{\mathrm{a}}$ & 0.19 \\
\hline ADG/DM intake & $0.144^{\mathrm{ef}}$ & $0.174^{\mathrm{e}}$ & $0.152^{\mathrm{ef}}$ & $0.133^{f}$ & $0.182^{\mathrm{e}}$ & 0.017 \\
\hline \multirow{2}{*}{\multicolumn{7}{|c|}{$\mathrm{a}, \mathrm{b}, \mathrm{c}, \mathrm{d}$ Least square means in the same row without a common superscript differ $(P<0.05)$}} \\
\hline${ }^{\mathrm{e}, \mathrm{f}}$ Least square means in the same row without a common superscript differ $(P \leq 0.10)$ & & & & & & \\
\hline \multirow{3}{*}{\multicolumn{7}{|c|}{$\begin{array}{l}{ }^{1} \text { Whole = Whole Upland cottonseed; Cracked = cracked Upland cottonseed; Roasted = roasted Upland } \\
\text { cottonseed; R-cracked = roasted-cracked Upland cottonseed; and Extruded = extruded Upland cottonseed. } \\
{ }^{2} \mathrm{TG}=\text { Total gossypol; FG = free gossypol; ADG = average daily BW gain. } \\
{ }^{3} \text { Plasma TG/TG intake in mg/kg of BW/d. }\end{array}$}} \\
\hline & & & & & & \\
\hline & & & & & & \\
\hline 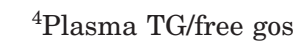 & & & & & & \\
\hline
\end{tabular}

and then roasting further reduced FG intake compared with only roasting.

The changes in TG and FG intake affected PG concentrations. Steers fed roasted-cracked Upland cottonseed, which resulted in the lowest FG intake, had the lowest plasma TG concentration. Concentrations of plasma TG were similar between steers fed extruded or roasted Upland cottonseed, but they were both lower $(P<0.05)$ than those in steers fed Upland cottonseed whole or cracked. Plasma TG concentrations reflected FG intake (Mena et al., 2001, 2004), and reducing the FG intake by the roasted-cracked cottonseed diet reduced plasma TG concentration. When the seed is cracked, more gossypol-producing glands are exposed to the heat of roasting, which reduces the FG content of the seed. This might explain the additional benefit of roasted-cracked cottonseed compared with only either roasting or cracking on plasma TG concentrations. Overall, PG concentrations were low for all treatments and there were no signs of overt gossypol poisoning in any of the steers.

Steers fed the extruded and roasted-cracked cottonseed diets had the lowest plasma TG response. However, extrusion of cottonseed resulted in the highest plasma FG response. These responses indicate that, although processing reduced FG intake and plasma TG concentrations, the reduction in plasma TG concentration was not proportional to the reduction in FG intake as milligrams/kilogram of BW/day. Factors other than processing affect availability of gossypol based on PG concentrations. Mena et al. (2001, 2004) suggested that particle size alters rumen retention time of cotton prod- ucts, which interferes with the ability of the rumen microflora to bind FG thereby affecting its availability and, consequently, PG concentrations. Cracking reduces particle size and possibly affects retention of seed in the rumen. However, in the current experiment, only numerical increases in plasma TG and plasma TG response were observed when linted WCS was cracked. Moreover, bound gossypol in heat-processed cottonseed, although considered unavailable, might be released in the digestive tract and become available for absorption, thereby affecting plasma TG concentrations (Calhoun et al., 1995).

\section{Experiment 3}

In experiment 3 , the Upland WCS contained $0.64 \%$ TG [58.8\% (+) and $41.2 \%(-)$ isomers] and $0.64 \% \mathrm{FG}$, whereas CSM contained $1.40 \%$ TG [60.8\% (+) and 39.2\% (-) isomers] and $0.11 \%$ FG. Therefore, all TG in WCS was in the free form, whereas only $7.8 \%$ of the TG was FG in CSM. Similar differences in TG and FG content of the 2 cotton products have been observed by others (Mena et al., 2001, 2004).

Body weight and DM intake of steers were not influenced by WCS or CSM (Table 7). In 2 experiments in which lactating dairy cows were fed diets varying in gossypol content from Upland WCS and CSM, neither BW nor DM intake differed among diets with at least $950 \mathrm{mg} / \mathrm{kg}$ TG (Mena et al., 2001, 2004). Similar to BW and DM intake, animal performance, as evaluated by average daily BW gain and feed efficiency, was similar 
Table 7. Effect of varying intake of total gossypol (TG) and free gossypol (FG) with whole cottonseed (WCS) and cottonseed meal (CSM) on plasma gossypol and performance of steers (experiment 3).

\begin{tabular}{|c|c|c|c|c|c|c|c|c|c|c|}
\hline \multirow{2}{*}{$\begin{array}{l}\text { Whole cottonseed, \%: } \\
\text { Cottonseed meal, \%: }\end{array}$} & \multicolumn{6}{|c|}{ Treatment $^{1}$} & \multirow[b]{2}{*}{ SEM } & \multicolumn{3}{|c|}{$P<^{2}$} \\
\hline & 2.8 & 5.7 & 8.5 & 2.8 & 5.7 & 8.5 & & WCS & CSM & $\times \mathrm{CSM}$ \\
\hline DMI, kg/d & 9.24 & 10.33 & 10.05 & 10.03 & 10.04 & 9.66 & 0.34 & 0.90 & 0.32 & 0.19 \\
\hline \multicolumn{11}{|l|}{ Total gossypol intake } \\
\hline $\mathrm{g} / \mathrm{d}$ & 7.89 & 13.25 & 17.14 & 13.81 & 17.33 & 20.63 & 0.62 & 0.001 & 0.001 & 0.17 \\
\hline $\mathrm{g} / \mathrm{d}$ & 4.84 & 5.56 & 6.07 & 10.08 & 10.27 & 9.82 & 0.30 & 0.001 & 0.22 & 0.08 \\
\hline $\mathrm{mg} / \mathrm{kg}$ of BW/d & 11.36 & 12.92 & 13.74 & 24.16 & 23.90 & 24.04 & 1.01 & 0.001 & 0.54 & 0.46 \\
\hline Plasma TG, $\mu \mathrm{g} / \mathrm{mL}$ & 0.68 & 1.05 & 1.35 & 2.78 & 2.25 & 3.00 & 0.34 & 0.001 & 0.31 & 0.43 \\
\hline${\text { Plasma TG } \text { response }^{3}}$ & 0.040 & 0.035 & 0.035 & 0.083 & 0.055 & 0.063 & 0.009 & 0.001 & 0.14 & 0.40 \\
\hline Plasma FG response $^{4}$ & 0.072 & 0.082 & 0.095 & 0.111 & 0.092 & 0.128 & 0.014 & 0.03 & 0.30 & 0.60 \\
\hline $\mathrm{ADG},{ }^{5} \mathrm{~kg} / \mathrm{d}$ & 1.15 & 1.15 & 1.07 & 1.19 & 1.04 & 1.40 & 0.19 & 0.58 & 0.77 & 0.52 \\
\hline ADG/DM intake & 0.121 & 0.112 & 0.105 & 0.120 & 0.098 & 0.153 & 0.018 & 0.45 & 0.40 & 0.22 \\
\hline
\end{tabular}

${ }^{1}$ WCS $7.0 \%$ and CSM $2.8 \%=500 \mathrm{mg} / \mathrm{kg}$ TG from WCS and $400 \mathrm{mg} / \mathrm{kg}$ TG from CSM; WCS $7.0 \%$ and CSM $5.7 \%=500 \mathrm{mg} / \mathrm{kg}$ TG from WCS and $800 \mathrm{mg} / \mathrm{kg}$ TG from CSM; WCS $7.0 \%$ and CSM $8.5 \%=500 \mathrm{mg} / \mathrm{kg}$ TG from WCS and $1200 \mathrm{mg} / \mathrm{kg}$ TG from CSM; WCS $14.0 \%$ and CSM $2.8 \%=1000 \mathrm{mg} / \mathrm{kg}$ TG from WCS and $400 \mathrm{mg} / \mathrm{kg}$ TG from CSM; WCS $14.0 \%$ and CSM $5.7 \%=1000 \mathrm{mg} / \mathrm{kg}$ TG from WCS and 800 $\mathrm{mg} / \mathrm{kg}$ TG from CSM; and WCS $14.0 \%$ and CSM $8.5 \%=1000 \mathrm{mg} / \mathrm{kg}$ TG from WCS and $1200 \mathrm{mg} / \mathrm{kg}$ TG from CSM.

${ }^{2} \mathrm{WCS} \times \mathrm{CSM}=$ Interaction between WCS and CSM.

${ }^{3} \mathrm{Plasma} \mathrm{TG} / \mathrm{TG}$ intake in $\mathrm{mg} / \mathrm{kg}$ of BW/d.

${ }^{4}$ Plasma TG/FG intake in $\mathrm{mg} / \mathrm{kg}$ of BW/d.

${ }^{5} \mathrm{ADG}=$ Average daily BW gain .

across all diets. Therefore, altering the ratios of WCS to CSM, which resulted in different combinations of TG and FG, had no influence on animal performance.

Total gossypol intake increased $(P<0.001)$ as more cotton products were fed to steers, but no interaction between WCS and CSM was observed. However, FG intake increased $(P<0.001)$ with increasing concentrations of WCS, but not with CSM. Because increasing CSM in the diet from 2.8 to $8.5 \%$ had a minor impact on the FG content of the rations, it was expected that feeding more CSM would increase the TG intake, but not FG intake by steers. When Mena et al. (2001, 2004) increased the TG content of the diets by raising the CSM content from 0 to $7.0 \%$ of the ration DM, TG intake increased, but FG intake as grams/day or as milligrams/ kilogram of BW/day remained at a similar level.

Plasma TG concentrations followed similar pattern as that of FG intake, and they increased $(P<0.001)$ with additional WCS in the diet, but not with CSM. It has been demonstrated that plasma TG concentrations were more positively correlated with FG than TG intake in lactating dairy cows (Mena et al., 2001, 2004). Therefore, as WCS and FG intake increased, plasma TG concentrations were also expected to increase. However, the low concentration of FG in CSM resulted only in minor numerical changes in plasma TG concentrations. Plasma TG response was greater $(P<0.001)$ for steers consuming the $14.0 \%$ WCS diets, but altering the content of dietary CSM had no impact on plasma TG response. Because CSM had a high content of TG, but most of it was in the bound form, therefore with little impact on PG concentrations (Mena et al., 2001, 2004), increasing dietary TG intake from CSM was expected to have no effect or even reduce plasma TG response. Similar to plasma TG response, plasma FG response was influenced $(P<0.03)$ by the higher dietary WCS, but not by altering dietary CSM. These data suggest that increasing CSM in the diet of steers had a minor effect on PG concentrations, but as dietary WCS increased and, thus FG intake, so did plasma TG concentrations. A possible explanation for the greater plasma TG and FG responses might be related to a reduced ability of the rumen to detoxify gossypol at higher intakes of FG when WCS was fed.

Although diets contained high concentrations of gossypol, and steers fed the diet containing $14.0 \%$ WCS and $8.5 \% \mathrm{CSM}$ had the highest plasma TG concentration $(3.00 \mu \mathrm{g} / \mathrm{mL})$, there were no signs of overt gossypol poisoning in any steers. These findings agree with those by Barraza et al. (1991) in which lactating Holstein cows consuming a diet with 15\% WCS and 15\% CSM, which provided $23 \mathrm{~g} / \mathrm{d}$ of $\mathrm{FG}$ and $58 \mathrm{~g} / \mathrm{d}$ of TG for 8 wk showed no signs of gossypol toxicity. In long-term studies, lactating dairy cows consuming $22.8 \mathrm{~g} / \mathrm{d}$ of FG from a blend of WCS and cracked Pima cottonseed for a period of $170 \mathrm{~d}$ had marked increases in PG, but neither gossypol intake nor PG concentrations affected health, culling, and mortality of cows; however, reproductive performance was compromised (Santos et al., 2003). Additional evidence of the ability of ruminants 
Table 8. Effect of type and processing of cottonseed on plasma total gossypol (TG) and performance of steers (experiment 4).

\begin{tabular}{|c|c|c|c|c|c|c|c|c|}
\hline \multirow[b]{3}{*}{ Parameter $^{2}$} & \multicolumn{4}{|c|}{ Type of cottonseed } & \multirow[b]{3}{*}{ SEM } & \multirow{2}{*}{\multicolumn{3}{|c|}{$P<1$}} \\
\hline & \multicolumn{2}{|c|}{ Upland } & \multicolumn{2}{|c|}{ Pima } & & & & \\
\hline & Whole & Cracked & Whole & Cracked & & Type & Processing & $\mathrm{T} \times \mathrm{P}$ \\
\hline BW, kg & 483.1 & 486.3 & 497.0 & 473.0 & 9.7 & 0.98 & 0.32 & 0.20 \\
\hline DMI, kg/d & 9.06 & 10.12 & 10.11 & 9.20 & 0.45 & 0.91 & 0.89 & 0.08 \\
\hline \multicolumn{9}{|l|}{ Total gossypol intake } \\
\hline $\mathrm{g} / \mathrm{d}$ & 10.06 & 9.75 & 11.96 & 10.85 & 0.63 & 0.04 & 0.30 & 0.55 \\
\hline $\mathrm{mg} / \mathrm{kg}$ of BW/d & 19.94 & 20.21 & 25.34 & 23.41 & 1.02 & 0.001 & 0.45 & 0.32 \\
\hline Plasma TG, $\mu \mathrm{g} / \mathrm{mL}$ & 1.95 & 2.69 & 2.54 & 4.01 & 0.42 & 0.05 & 0.02 & 0.36 \\
\hline Plasma TG response & 0.089 & 0.119 & 0.125 & 0.165 & 0.016 & 0.03 & 0.05 & 0.77 \\
\hline $\mathrm{ADG}, \mathrm{kg} / \mathrm{d}$ & 1.28 & 1.55 & 1.42 & 1.00 & 0.20 & 0.27 & 0.71 & 0.08 \\
\hline ADG/DM intake & 0.128 & 0.151 & 0.145 & 0.109 & 0.017 & 0.47 & 0.72 & 0.11 \\
\hline
\end{tabular}

${ }^{1}$ Type $=$ effect of type of cottonseed (Upland vs. Pima); Processing = effect of processing method (whole vs. cracked); $\mathrm{T} \times \mathrm{P}=$ interaction between type of cottonseed and processing method.

${ }^{2}$ Plasma TG response = plasma TG/TG intake in $\mathrm{mg} / \mathrm{kg}$ of $\mathrm{BW} / \mathrm{d} ; \mathrm{ADG}=$ average daily $\mathrm{BW}$ gain.

to consume large quantities of TG and FG without displaying clinical signs of gossypol toxicity is supported by observations from Noftsger et al. (2000), who showed no signs of clinical gossypol toxicity when primiparous and multiparous cows consumed 21.6 and $30.9 \mathrm{~g} / \mathrm{d}$ of FG from WCS, respectively, from 30 to $120 \mathrm{~d}$ in lactation.

\section{Experiment 4}

In experiment 4 , linted Upland WCS contained $0.64 \%$ TG [58.8\% (+) and $41.2 \%(-)$ isomers] and Pima WCS contained $0.80 \%$ [46.7\% (+) and 53.3\% (-) isomers] TG. All TG in Upland and Pima cottonseeds was in the free form, so description of TG also refers to FG. Results of analyses of cottonseeds are similar to observed by others (Sullivan et al., 1993a,b; Santos et al., 2002, 2003; Prieto et al., 2003; McCaughey et al., accepted) in which Pima contained more gossypol than Upland, and more of the TG in Pima was represented by the (-) isomer, whereas for the Upland, more of the TG was represented by the (+) isomer. Furthermore, the reduced fiber content of Pima, because of lack of lint, resulted in diets with less ADF and NDF (Table 4).

Type of cottonseed and processing method had no influence on BW, daily BW gain, DM intake, and feed efficiency of steers (Table 8). The effects of type of cottonseed on DM intake have been mixed. Lactating dairy cows fed linted Upland WCS had DM intakes similar to (Sullivan et al., 1993a,b; Santos et al., 2002; Prieto et al., 2003) or lower than cows fed cracked Pima cottonseed (McCaughey et al., accepted). Processing of Pima cottonseed by cracking or grinding usually improved feed efficiency in lactating dairy cows (Sullivan et al., 1993a,b), which disagrees with our findings with steers. Improved efficiency of nutrient use when Pima cottonseed is either cracked or ground is thought to be caused by the increased fatty acid digestibility and reduced excretion of whole seed in the feces (Sullivan et al., 1993a,b).

Intake of TG increased $(P=0.04)$ with feeding of Pima cottonseed because of the greater concentration of TG of the Pima seed compared with Upland seed. As a result, gossypol intake per kilogram of BW also increased $(P<0.01)$ with feeding of Pima cottonseed. These results were expected because feeding Pima cottonseed increased TG intake by dairy cows (Santos et al., 2002; Prieto et al., 2003; McCaughey et al., accepted). The increased gossypol intake by steers fed Pima cottonseed resulted in greater $(P<0.05)$ plasma TG concentrations. Similarly, cracking of cottonseeds increased plasma TG concentrations in spite of no changes in gossypol intake, which suggests that cottonseeds have a greater impact on PG concentrations when fed as cracked than whole.

Plasma TG response, a measure of changes in PG relative to TG intake in $\mathrm{mg} / \mathrm{kg}$ of $\mathrm{BW} / \mathrm{d}$, was greater $(P=0.03)$ for steers fed the Pima diets, and cracked cottonseeds $(P=0.05)$. This indicates that the increases in plasma TG were greater with similar consumption of TG per kilogram of BW per day when steers were fed Pima compared with Upland cottonseed, or when cottonseed was processed by cracking. Similar responses were observed by Santos et al. (2002, 2003) when partial replacement of Upland WCS with cracked Pima cottonseed increased FG intake by $32.0 \%$, but PG concentrations more than tripled in dairy cows. Prieto et al. (2003) also observed nonproportional increases in PG with increasing in gossypol intake when cracked Pima cottonseed replaced Upland WCS. Therefore, gossypol in Pima cottonseed has a greater influence on plasma concentrations of gossypol than that of Upland cottonseed. A possible explanation for these results is 
that gossypol in Pima cottonseed or in cracked cottonseeds might be less detoxified in the forestomachs. Pima does not contain the linters, which might affect rumen retention time. Lack of lint in cottonseed affected the passage of the seed through the digestive tract of cattle (Coppock et al., 1987), suggesting less retention of the seed in the rumen. Moreover, when the cottonseed is cracked, particle size and density of the seed are altered (Santos et al., 2002), which results in increased passage rate though the rumen-reticulum, thereby affecting detoxification (Santos et al., 2002, 2003; Prieto et al., 2004). Even though plasma TG concentration was highest for the steers fed the cracked Pima diet $(4.01 \mu \mathrm{g} /$ $\mathrm{mL}$ ), with individual animals with plasma TG up to $6.71 \mu \mathrm{g} / \mathrm{mL}$, there were no signs of overt gossypol poisoning in any steers.

\section{Relationships Between PG and Gossypol Intake}

Data from experiments 2 and 3 , in which steers were fed different concentrations of TG and FG were used to evaluate the correlations between PG concentrations and gossypol intake. For experiment 2, a linear relationship between plasma TG concentration and gossypol intake was determined $(P<0.0001)$, and FG intake in grams/day or in milligrams per kilogram of $\mathrm{BW}$ per day explained more of the variation in plasma $\mathrm{TG}\left(\mathrm{r}^{2}=0.56\right)$ than did consumption of TG in grams/day $\left(\mathrm{r}^{2}=0.41\right)$ or in milligrams per kilogram of BW per day $\left(\mathrm{r}^{2}=0.45\right.$; Figure 1). For experiment 3, a similar linear relationship between plasma TG concentration and gossypol intake was also determined $(P<0.0001)$, and FG intake in milligrams per kilogram of BW per day explained more of the variation in plasma TG $\left(\mathrm{r}^{2}=0.67\right)$ than did consumption of TG in grams/day $\left(r^{2}=0.21\right)$ or in milligrams per kilogram of BW per day $\left(\mathrm{r}^{2}=0.34\right.$; Figure 1). These results are similar to those observed by Mena et al. (2001, 2004) in which FG intake was the best predictor for PG concentrations. Gossypol in the free form is considered more available for absorption based on changes in PG concentrations, but TG also includes bound gossypol, which is considered unavailable in the digestive tract (Reiser and Fu, 1962; Calhoun et al., 1995). Although it has been suggested that bound gossypol might be released in the digestive tract and become available for absorption, the current data suggest that intake of FG has a greater influence on PG concentrations than does intake of bound or TG.

\section{CONCLUSIONS}

The feeding of diets containing $15.0 \%$ cottonseed to 5 -mo-old Holstein steers for 5 mo did not result in gossypol toxicity. When supplemental Fe as iron sulfate was
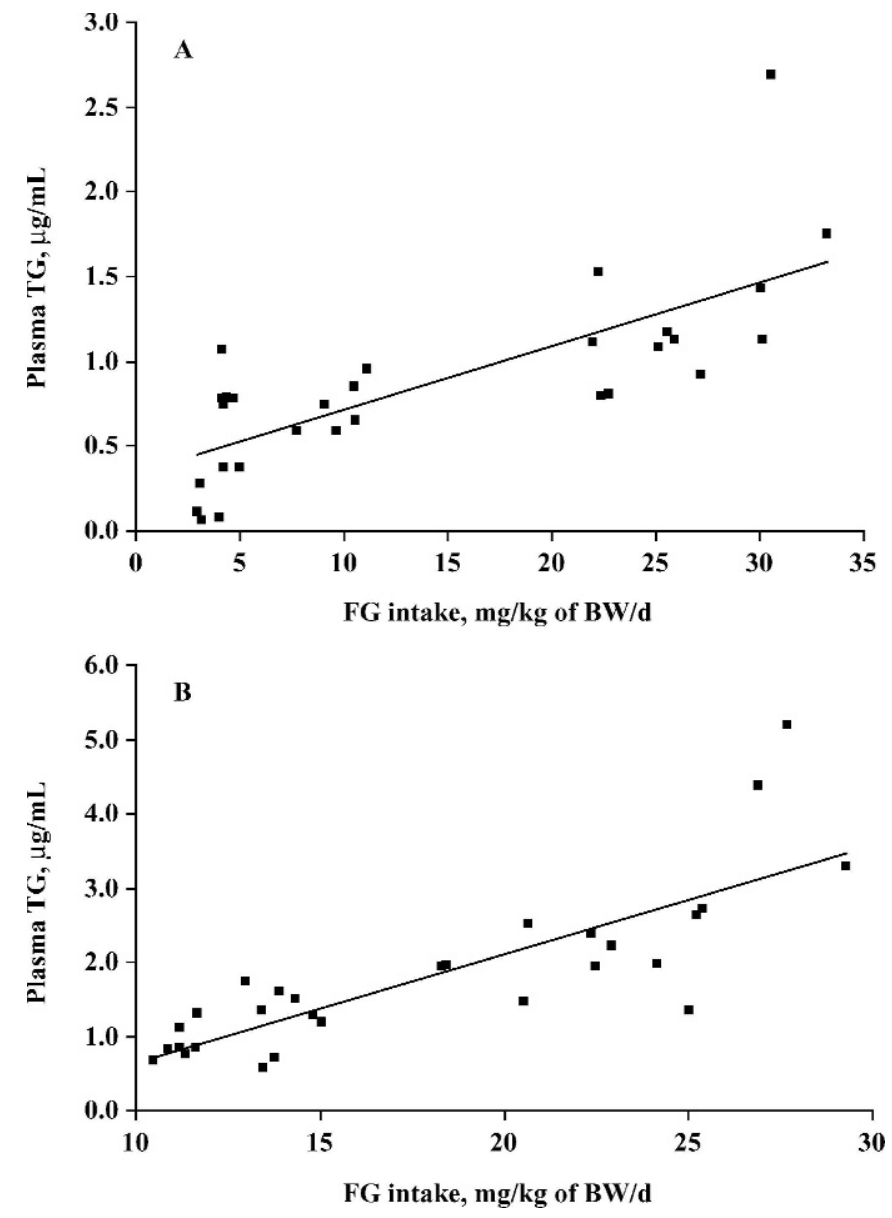

Figure 1. Relationship between free gossypol (FG) intake and plasma total gossypol (TG) concentration in steers consuming Upland cottonseed fed as whole, coarsely cracked, roasted, coarsely cracked and roasted, or extruded in experiment 2 (A), or combinations of Upland whole cottonseed and cottonseed meal in experiment 3 (B). For panel A, plasma TG $=0.345876+0.0371838 \mathrm{FG}$, where plasma TG was determined in $\mu \mathrm{g} / \mathrm{mL}$, and FG intake was expressed in $\mathrm{mg} /$ $\mathrm{kg}$ of BW/d $\left(P<0.0001 ; \mathrm{r}^{2}=0.56\right)$. For panel B, plasma TG $=-0.811465$ $+0.145906 \mathrm{FG}$, where plasma TG was determined in $\mu \mathrm{g} / \mathrm{mL}$, and FG intake was expressed in $\mathrm{mg} / \mathrm{kg}$ of BW/d $\left(P<0.0001 ; \mathrm{r}^{2}=0.67\right)$.

added to the diet up to $600 \mathrm{mg} / \mathrm{kg}$, intake of $\mathrm{DM}$ and gossypol, and PG concentrations decreased linearly, with no effect on average daily weight gain or feed efficiency. The decline in PG concentration with supplemental Fe was observed despite the lower gossypol intake, which suggests that supplemental Fe reduced gossypol availability in the digestive tract as reflected by the lower PG concentrations. Processing of cottonseed by roasting or extrusion reduced FG content of the seed, with roasted-cracked cottonseed being the most effective processing method at reducing both TG and FG concentrations of the seed. This reduction in gossypol content of the seed reflected in reduced concentrations of plasma TG, with minor changes in animal perfor- 
mance. Altering the ratio of WCS to CSM to manipulate the contents of TG and FG of the diet had no impact on performance of steers. However, as dietary FG intake increased with more WCS, so did plasma TG concentrations and plasma TG and FG responses. These data indicate that increasing FG intake by feeding more WCS reduces the ability of the rumen to detoxify gossypol as evaluated the by greater plasma TG response. Nevertheless, altering the TG content of the diet by feeding up to $8.5 \%$ CSM had no effect on PG. Pima cottonseed contained more TG and FG than Upland cottonseed, which resulted in greater plasma TG concentrations and plasma TG response. When the Pima and Upland cottonseed were processed by cracking, gossypol availability increased as reflected by the greater plasma TG concentrations and plasma TG response.

\section{ACKNOWLEDGMENTS}

The authors wish to thank Millard C. Calhoun and B. C. Baldwin, Jr. (Texas Agricultural Experiment Station, San Angelo) for analyses of gossypol in cotton products and plasma, and for suggestions during the study, and Giawad Gheniwa (University of Arizona) for assistance during laboratory analyses. Our appreciation is also extended to David Kinard (National Cottonseed Products Association), Andy Jordan (The Cotton Foundations), Lee Todd (Southern Cotton Ginners Association), and Tom Wedegaertner (Cotton Incorporated) for their financial support.

\section{REFERENCES}

American Oil Chemist's Society (AOCS). 1985a. Determination of free gossypol. Official Method Ba 7-58. Official and Tentative Methods of Analysis. 3rd ed. Amer. Oil Chem. Soc., Chicago, IL.

American Oil Chemist's Society (AOCS). 1985b. Determination of total gossypol. Official Method Ba 8-78. Official and Tentative Methods of Analysis. 3rd ed. Amer. Oil Chem. Soc., Chicago, IL.

AOAC. 1990. Official Methods of Analysis. 15th ed. Association of Official Analytical Chemists, Arlington, VA.

Arieli, A. 1998. Whole cottonseed in dairy cattle feeding: A review. Anim. Feed Sci. Technol. 72:97-110.

Barraza, M. L., C. E. Coppock, K. N. Brooks, D. L. Wilks, R. G. Saunders, and G. W. Latimer, Jr. 1991. Iron sulfate and feed pelleting to detoxify free gossypol in cottonseed diets for dairy cattle. J. Dairy Sci. 74:3457-3467.

Calhoun, M. C., S. W. Kuhlmann, and B. C. Baldwin. 1995. Assessing the gossypol status of cattle fed cottonseed products. Pages 147A157A In Proc. Pacific Northwest Anim. Nutr. Conf. Portland, OR. University of Idaho, Moscow.

Coppock, C. E., J. K. Lanham, and J. L. Horner. 1987. A review of the nutritive value and utilization of whole cottonseed, cottonseed meal and associated by-products by dairy cattle. Anim. Feed Sci. Technol. 18:89-129.

Hron, R. J., H. L. Kim, M. C. Calhoun, and G. S. Fisher. 1999. Determination of $(+),(-)$, and total gossypol in cottonseed by high performance liquid chromatography. J. Am. Oil Chem. Soc. 76:1351-1355.

Joseph, A. E. A., S. A. Matlin, and P. Knox. 1986. Cytotoxicity of enantiomers of gossypol. Br. J. Cancer 54:511-514.

Kim, H. L., and M. C. Calhoun. 1995. Determination of gossypol in plasma and tissues of animals. Inform 6:486. (Abstr.)

Kuehl, R. 1994. Complete block designs. Pages 256-305 in Statistical Principles of Research Design and Analysis, R. Kuehl, ed. Wadsworth Publishing Co., Belmont, CA.

Lewkowitz, M. 2004. 2004/05 crop year USDA-NASS production forecast. Online. Available http://www.supimacotton.org/. Accessed Oct. 18, 2004

Littell, R. C., W. W. Stroup, and R. J. Freund. 2002. SAS for linear models, 4th ed. SAS Institute Inc., Cary, NC.

McCaughey, K. M., E. J. DePeters, P. H. Robinson, J. E. P. Santos, J. W. Pareas, and S. J. Taylor. Impact of feeding whole Upland cottonseed, with or without cracked Pima cottonseed with increasing addition of iron sulfate, on productivity and plasma gossypol of lactating dairy cattle. Anim. Feed Sci. Technol. (accepted)

Mena, H., J. E. P. Santos, J. T. Huber, J. M. Simas, M. Tarazon, and M. C. Calhoun. 2001. The effects of feeding varying amounts of gossypol from whole cottonseed and cottonseed meal in lactating dairy cows. J. Dairy Sci. 84:2231-2239.

Mena, H., J. E. P. Santos, J. T. Huber, M. Tarazon, and M. C. Calhoun. 2004. The effects of feeding varying amounts of gossypol from whole cottonseed and cottonseed meal on lactation performance and metabolism of dairy cows. J. Dairy Sci. 87:2506-2518.

Minitab Inc. 2000. Minitab Release 13.2, Reference Manual II. Minitab Inc., State College, PA.

Noftsger, S. M., B. A. Hopkins, D. E. Diaz, C. Brownie, and L. W. Whitlow. 2000. Effect of whole and expanded-expelled cottonseed on milk yield and blood gossypol. J. Dairy Sci. 83:2539-2547.

NRC. 2001. Nutrient Requirements of Dairy Cattle. 7th rev. ed. Natl. Acad. Sci., Washington, DC.

Prieto, J. G., E. J. DePeters, P. H. Robinson, J. E. P. Santos, J. W. Pareas, and S. J. Taylor. 2003. Increasing dietary levels of cracked Pima cottonseed increase plasma gossypol but do not influence productive performance of lactating Holstein cows. J. Dairy Sci. 86:254-267.

Reiser, R., and H. C. Fu. 1962. The mechanism of gossypol detoxification by ruminant animals. J. Nutr. 76:215-218.

Risco, C. A., A. L. Adams, S. Seebohm, M. J. Thatcher, C. R. Staples, H. H. Van Horn, L. R. McDowell, M. C. Calhoun, and W. W. Thatcher. 2002. Effects of gossypol from cottonseed on hematological responses and plasma alpha-tocopherol concentration of dairy cows. J. Dairy Sci. 85:3395-3402.

SAS Institute. 2001. SAS/STAT User's guide (release 8.2). SAS Inst. Inc., Cary, NC.

Santos, J. E. P., M. Villaseňor, E. J. DePeters, P. H. Robinson, and B. C. Baldwin. 2002. Type of cottonseed and gossypol in diets of lactating dairy cows: Lactation performance and plasma gossypol. J. Dairy Sci. 85:1491-1501.

Santos, J. E. P., M. Villaseňor, E. J. DePeters, P. H. Robinson, and C. H. Holmberg. 2003. Type of cottonseed and gossypol in diets of lactating dairy cows: Plasma gossypol, reproduction, and health. J. Dairy Sci. 86:892-905.

Sullivan, J. L., J. T. Huber, and J. M. Harper. 1993a. Performance of dairy cows fed short staple, Pima, and cracked Pima cottonseed and feed characteristics. J. Dairy Sci. 76:3555-3561.

Sullivan, J. L., J. T. Huber, R. L. Price, and J. M. Harper. 1993b. Comparison of digestibility, nutritive value, and storage characteristics of different forms of cottonseed in diets fed to lactating dairy cows J. Anim. Sci. 71:2837-2842.

Van Soest, P. J., J. B. Robertson, and B. A. Lewis. 1991. Methods for dietary fiber, neutral detergent fiber, and nonstarch polysaccharides in relation to animal nutrition. J. Dairy Sci. 74:35833596 . 